\title{
Human capital - a pillar of sustainable development. Empirical evidences from the EU states
}

\author{
Associate Professor Laura DIACONU (MAXIM) ${ }^{1}, \mathrm{PhD}$. \\ Associate Professor Cristian C. POPESCU², PhD.
}

\begin{abstract}
The idea according to which human capital is the main engine of growth has a large support in the specialized literature. In this context, the analysts have argued that sustainable growth and development of a country relies not on a large number of people but on a large amount of human capital. The explanation is simple: a healthier and better educated society involves more productive people, who are able to efficiently evaluate the opportunities and to take the right decisions, a higher social cohesion and more "green skills" that raise the environmental awareness. Considering all these aspects, the main objective of this paper is to identify the way in which human capital, through its qualitative dimensions, influences the sustainable development in the EU states. In order to reach this purpose, we have collected, tabulated and analysed the secondary data offered by various statistical yearbooks, reports and by different empirical investigations. The conclusions of this study may offer valuable information for the EU policy makers regarding the importance of investing in human capital in order to ensure a sustainable development.
\end{abstract}

Keywords: buman capital, sustainable development, economic growth, social cohesion, environment protection

\section{Introduction}

The satisfaction of the human needs and aspirations has always been the major objective of the development. However, during the last decades, this objective has not been pursued in a sustainable way since it led to environmental degradation and to many socio-economic imbalances, such as massive destruction of the natural ecosystems and land degradation, increases in soil, air and water contamination, accumulation of enormous amounts of waste, global climate changes, alarming increases in the population of the less developed countries, food crisis and widening the gap between the poor and the rich ones.

Since the emergence of the new economic growth theories, the human capital has been considered the most critical aspect of the development. Actually, it has largely been argued that the only chance to reduce the gap between the less developed and the developed countries is to increase the level of education of the first ones. In this context, some analysist, such as Baumol, Nelson and Wolf (1994) are talking about ,a convergence club", which includes a group of countries for which the convergence principles can be applied. They argue that only the states with an adequate initial level of human capital endowment can take advantages of the modern technology and, consequently, are able to experience a convergent growth. Moreover, they show that

"Alexandru Ioan Cuza" University of Iași, Faculty of Economics and Business Administration, Department of Economics and International Relations, Carol I Avenue, no. 22, Iasi, Romania.

2 "Alexandru Ioan Cuza" University of Iași, Faculty of Economics and Business Administration, Department of Economics and International Relations, Carol I Avenue, no. 22, Iasi, Romania. 
while the developing countries, with average revenues, can surpass the technological gap, "borrowing" technology from abroad, the poorest ones cannot overpass the knowledge and technological differences. This idea is also argued by Harmon, Oosterbeek and Walker (2000) who consider that more educated countries grow faster because the education gives the opportunity to create new technologies and adapt the existing ones to local production. Consequently, the opportunities to grow may be greater for the economies that are inside the technological frontiers (Barro and Sala-i-Martin, 1995).

A study conducted by Slaus and Jacobs (2011) argue that all forms of capital - natural, social, technological, financial and human - constantly interact, influencing the sustainable economic growth. However, they consider that the human capital is the central determinant of the resource productivity and sustainability.

Considering all these aspects, the main objective of the present paper is to identify the way in which human capital, through its qualitative dimensions, influences the sustainable development in the EU states. In order to reach this purpose, we have used two research methods. Firstly, we have conducted a documentary study of the specialized literature and, secondly, we have collected, tabulated and analysed the secondary data offered by various statistical yearbooks and reports. Some of the data was analysed with the help of the SPSS program.

The paper is structured on two main parts. The first one includes a literature review regarding the relationship between the human capital and the economic, social and ecologic aspects involved by the sustainable development concept. In the second part, based on the statistical information, we present some empirical evidences regarding this relationship in the case of the EU states.

\section{Theoretical background of the relationship between the human capital and the sustainable development}

\subsection{Human capital and economic growth}

The human capital theories underline how education increases the productivity and efficiency of workers by augmenting the level of the cognitive stock of the economically productive human capability (Olaniyan and Okemakinde, 2008). In other words, better educated people will have a higher level of productivity and creativity, fact that will stimulate the technological progress. Lall and Kramer-Mbula (2005) consider that the developing states cannot simply import technologies without investing in building 'capabilities' to learn how to master, acquire, adapt and improve the existing technologies. These capabilities involve acquiring new skills and knowledge. SalazarXirinachs, Nübler and Kozul-Wright (2014) argue that the productive capabilities lead to economic diversification and generate the competences necessary to take advantage of potential opportunities. The same idea has been previously debated by Sturm (1993), who considered that the highly skilled individuals may better evaluate the new opportunities because they can easily distinguish between random and systematic elements of the economic changes. Therefore, a higher level of education leads to a better participation in the global economy. Moreover, the high-skilled persons will have the chance to earn higher wages, to have a lower unemployment rate, a higher mobility and a better employment opportunity during their active lives.

The specialized literature has also argued that the human capital of an individual is 
more productive when the other members of the society are more skilled (Lange and Topel, 2006), resulting some spill-over effects from technical progress/knowledge accumulation. This aspect has been previously mentioned by Marshall (1890), who noted that the social interaction among individuals that work in the same industry and in the same place develops new opportunities to learn, fact that increases their productivity.

Apart from these direct effects on economic growth and development, the education may foster the welfare state through some indirect externalities such as: improvements in health and nutrition level, offering opportunities for personal fulfilment and developing some individual abilities (Haveman and Wolfe, 1984). To these consequences with indirect positive impact on the economic growth, McMahon (1999) adds the fact that the well-educated people will contribute to improvements in the democracy process, to enforcing the rule of law and to political stability. On medium and long term, all these aspects will be definitely reflected in the economic growth process.

Trying to answer the question 'why the performance of poor countries are so weak?', the analysts have concluded that another main factor, together with the low level of education, is the low level of health. Despite the fact that the life expectancy has increased dramatically in the developing countries over the past fifteen years, many people from poor countries still face difficult health conditions. Health is seen as a good derived both from private and public funds, the share of these two financing sources varying from country to country, in some states the private funds prevailing, while in others - the public subsidies.

Different theories regarding the economic growth offer different answers on how the health conditions can influence, over time, the GDP per capita of a country (Barro, 1996). For example, the neoclassical theory of Solow (1956) and Swan (1956) regarding the economic growth claim that, over a long period of time, only the level of GDP per capita will be affected by the level of health and not the growth rate, which, in turn, is influenced by the overall rate of the technological progress. Unlike this opinion, the first endogenous growth models, in which the rate of technological progress differs among countries depending on the local economic conditions, see a direct impact of health on the growth rate. The health of an adult is directly linked to physical work capacity. The healthier an individual is, the more productive capacity will have. When labour productivity is high, the income level is also high.

The positive relationship between the level of health and the economic growth has also been statistically tested by Bloom, Canning and Sevilla (2004). Starting from a production function model of aggregate economic growth, their results show that a good level of health has a positive, sizable and statistically significant effect on the aggregate output. Moreover, they conclude that the life expectancy's effect in growth regressions is a real labour productivity effect and not the result of the life expectancy acting as a proxy for worker experience

\subsection{Human capital and environment protection}

In order to reduce or even stop the environmental problems, the analysts consider that the environmental awareness must be done from early ages, in school. Various OECD countries have already incorporated environmental topics into their curricula, focusing on issues like recycling, daily consumption habits and sustainable 
behaviours.

In 2006, when the last PISA round on science issues took place, the highest percentage of students (around 30\%) who performed at the highest level of proficiency were from Finland, Japan and Canada (OECD, 2009). In the opposite situation there were the students from Mexico, Turkey and Italy, where the percentage of the individuals who obtained the lowest proficiency level was around 30\%. These results are alarming since the students with the lowest grades were unable to answer questions about basic environmental phenomena.

An OECD report conducted in 2008 shows that the performance of the students in the environmental science is closely related to their performance in traditional science courses (such as physics, biology and chemistry). This conclusion suggests that better general knowledge about science can increase students' proficiency in environmental issues.

In the context of the discussion related to increasing the environmental awareness through education, several concepts have emerged: 'green skills', 'green graduates' and 'green innovations'. 'Green skills' are those abilities, values and attitudes that people need in order to maintain a resource-efficient society (Cedefop, 2012). These skills need to be created through the educational system to actively engage in protecting the environment. Moreover, in the context in which ILO (2013) estimates that up to 2030 about 20 million jobs will be created in the renewable energy sector, the future graduates need to have the proper abilities required by these fields.

Considering all these aspects, it is assumed that the universities are a significant contributor to the mitigation of the climate change, since they can generate the human capital on environmental issues required by their region (Mora et al., 2006). The number of the so-called 'green graduates' - those who received university degrees in environmental protection and physical sciences such as climatic research, meteorology or atmospheric research - was of 220,000 students, in 2011 (OECD, 2012a). For them, the university offered not only the skills but also the motivation of searching a 'green job'. Yet, it is considered that to develop the proper skills, the universities have to cooperate with the employers and with the research institutes.

The 'green innovation' consists in those inventions that help us use the natural resources more sustainably or solve difficult technological challenges. Therefore, they are essential in the transition to a green economy. An example in this direction was offer by the Copenhagen Cleantech Cluster, which took an innovative approach to solve global environmental challenges through local innovation.

According to the OECD statistics, Japan and USA are the market leaders in the green innovation, measured in the number of patents, closely followed by Germany and South Korea. Apart from the OECD states, China has also increased the number of the registered patents in environmental technologies by more than 2500\% between 1999 and 2011 (OECD, 2012b).

\subsection{Human capital and social cohesion}

Sianesi and Van Reenen (2000) note the fact that a higher level of education may be correlated not only to a friendly environment, but also to a better political and community implication, a higher social cohesion and to a lower criminality rate. 
Regarding the lower criminality rate, the opinions are divided. Freeman (2000), for example, considers that there is no clear direct relation between the educational level and the criminality rate. Meanwhile, Kelly (2000) argues that between the two variables there is an indirect connection: while different educational levels lead to income differences, these inequalities will increase the criminality rate. The same idea has previously been discussed by Leigh (1998), who considers that a higher level of education is positive and direct correlated to the crime absence. This direct relationship has also been statistically tested by Lochner (1999), who concluded that the states with a higher school enrolment rate and with a strict legislation have the lowest criminality index.

Analysing the causes of income inequalities, Wilkinson and Marmot (2003) believes that, in the advanced capitalist countries, a higher gap in the revenues' levels leads to lowered social cohesion which, in turn, produces poorer health status.

According to Schuller (2001), the social cohesion is both a consequence of and a producer of the social capital. The presence or the absence of the social capital depends on the level of education. This is argued by Dwiningrum (2013) through the fact that the elements involved by the social capital (social reds, trust and norms) can be acquired during the formal, non-formal and informal education. She supports this idea with the results of an empirical investigation conducted on teachers and principals from 17 elementary schools, 18 lower secondary schools and 16 high schools from Indonesia. The conclusions highlight the fact that the family, the school and the community have a very important role in shaping the individual character which will largely influence the social capital. Moreover, the social relations in the structure of a society have a role in developing the nation's cultural identity.

Clemente, Marcuello, Montañes and Pueyo (2004) have conducted an empirical study on the case of Spain. Their research highlights that there is a strong correlation between social and human capital and both of them have favoured the economic growth in Spain in the beginning of the XXIst century. The explanation for the close connection between social and human capital is simple: a higher level of education leads to higher revenues which will increase the individual satisfaction; the more fulfilled a person is, the higher the social cohesion will be.

The strong correlation between the human capital and the social cohesion is also proven by the Cypriot Operational Program "Employment, Human Resources and Social Cohesion", 2014-2020, in which the direct objective is the improvement in the vocational and technical educational system, in order to increase the employment rate and the social cohesion (European Commission, 2015).

\section{Empirical evidences from the EU states}

In order to identify the relationship between the sustainable development and the human capital in the EU states, some composite indicators have to be analysed. First of all, we have taken into consideration the Human Sustainable Development Index (HSDI), which has been introduced in 2011 by Togtokh as a way to amend the United Nations' Human Development Index (HDI), by adding an environmental dimension. Actually, the new HSDI takes into account not only the values of the HDI, but also the per capita carbon emission. Secondly, we have focused on the HDI, which is 
a measure of the average achievement in key dimensions of human development: a long and healthy life, being knowledgeable and have a decent standard of living. This indicator was considered in order to see if there are any changes among countries, from the point of view of the development, when the sustainability issues are taken into account. Thirdly, we have analysed the Human Capital Index (HCI), which quantifies how countries are developing and deploying their human capital. It includes four major pillars: health and wellness, education, workforce and employment and enabling environment.

Table 1 presents the world rankings, regarding the 2010 values of HDI, HSDI and HCI, of the first ten countries with the highest HSDI in the European Union. We have chosen the first ten countries with the highest HSDI in the European Union in order to see if their high levels of sustainable development also reflect high level of human capital endowment.

Table 1: Position of some EU states in the world ranking according to the HDI, HSDI and HCI, in 2010

\begin{tabular}{|c|c|c|c|}
\hline Country & HSDI world ranking & HDI world ranking & HCI world ranking \\
\hline Sweden & 3 & 9 & 5 \\
\hline France & 5 & 14 & 21 \\
\hline Ireland & 6 & 5 & 20 \\
\hline Netherland & 7 & 7 & 4 \\
\hline Germany & 9 & 10 & 29 \\
\hline Spain & 14 & 20 & 9 \\
\hline Denmark & 16 & 19 & 11 \\
\hline Belgium & 17 & 18 & 37 \\
\hline Italy & 18 & 23 & 55 \\
\hline Greece & 19 & 22 & \\
\hline
\end{tabular}

Source: Adaption from Togtokh (2011), World Economic Forum (2013) and United Nations (2015)

As it results from Table 1, the top ten countries with the highest levels of HSDI in European Union are also among the first 20 countries in the world, from the point of view of the same index. Moreover, they are also included by the United Nations' report in the group of countries with "very high human development" (United Nations, 2015). Regarding the level of human capital, we can see that some of the countries with higher position in the HSDI rank have also high levels of HCI. Among the exceptions, we can find Ireland and France which, despite the fact that they are in the top 3 from the point of view of the HSDI, are placed on the 9th and 10th positions among the EU states, regarding the HCI. Moreover, Spain, Italy and Greece, which are in the top 10 HSDI EU states, cannot be found among the first $10 \mathrm{HCI}$ EU countries. Actually, Greece is on the penultimate positions in the HCI ranking of the EU states (World Economic Forum, 2013).

In order to see if there is a relationship between the positions occupied by the ten countries presented in Table 1 in the three rankings (according to HDI, HSDI and HCI), we have conducted a bivariate correlation analysis, based on Spearman coefficient. Data was processed with the help of the SPSS program. The results of this analysis can be seen in Table 2 . 
Table 2: Correlation between the positions of the ten countries from Table 1 in the HSDI, HDI and HCI rankings, in 2010

\begin{tabular}{|c|c|c|c|c|c|}
\hline & & & HSDI & HDI & HCI \\
\hline \multirow[t]{3}{*}{$\begin{array}{l}\text { Spearman's } \\
\text { rho }\end{array}$} & HSDI & $\begin{array}{l}\text { Correlation Coefficient } \\
\text { Sig. (2-tailed) } \\
\text { N }\end{array}$ & $\begin{array}{l}1,000 \\
10\end{array}$ & $\begin{array}{l}, 806^{* *} \\
, 005\end{array}$ & $\begin{array}{l}, 576 \\
, 082 \\
10\end{array}$ \\
\hline & HDI & $\begin{array}{r}\text { Correlation Coefficient } \\
\text { Sig. (2-tailed) } \\
\mathrm{N}\end{array}$ & $\begin{array}{l}, 806^{* *} \\
, 005 \\
10\end{array}$ &. & $\begin{array}{l}733^{*} \\
, 016 \\
10\end{array}$ \\
\hline & HCI & $\begin{array}{r}\text { Correlation Coefficient } \\
\text { Sig. (2-tailed) } \\
\mathrm{N}\end{array}$ & $\begin{array}{l}, 576 \\
, 082 \\
10\end{array}$ & $\begin{array}{l}, 733^{*} \\
, 016\end{array}$ & $\begin{array}{l}1,000 \\
10\end{array}$ \\
\hline
\end{tabular}

Source: Own research

As we can see from Table 2, there is a strong positive correlation between the positions of the ten EU states in the HSDI, HDI and HCI rankings. These results lead to the conclusion that the states with the highest level of development in the EU have also taken into consideration the environmental issues, in order to ensure a sustainable development. Moreover, based on the results presented in Table 2, we can say that an important aspect for obtaining a sustainable development is accumulating a high stock of human capital. We can see from our analysis that countries that have leading positions in the HSDI ranking are also among the states with the highest levels of HCI.

To see the changes in the HDI, HSDI and HCI positions of the EU countries, we have also analysed these indicators for 2014 (see Table 3). As in the case of 2010, we have included in Table 3 only the first ten countries with the highest HSDI in the European Union. According to the information from Table 3, we can notice that two countries, Belgium and Greece, which were in 2010 in the top 10 states with highest levels of HSDI in European Union, are no longer in this ranking in 2014. Their places were taken by Austria and United Kingdom. Meanwhile, Germany, Ireland and Denmark have increased their HSDI during the four years, being placed on higher places in this ranking. However, Germany has lost positions in the HCI ranking. Sweden has maintained its leading position in the HSDI ranking and the second place in the HCI ranking,during the period 2010 and 2014. Another country that has maintained a relatively constant position in both rankings during the analysed period was Italy. As in the case of 2010 ranking, all the states considered to be the top 10 leading countries in the EU from the point of view of the HSDI are also included by the United Nations' report in the group of states with "very high human development" (United Nations, 2015).

Table 3: Position of some EU states in the world ranking according to the HDI, HSDI and HCI, in 2014

\begin{tabular}{|l|c|c|c|}
\hline Country & HSDI world ranking & HDI world ranking & HCI world ranking \\
\hline Sweden & 6 & 14 & 6 \\
\hline Germany & 8 & 6 & 22 \\
\hline Ireland & 9 & 6 & 12 \\
\hline Denmark & 10 & 4 & 7 \\
\hline Netherland & 11 & 5 & 8 \\
\hline France & 12 & 22 & 14 \\
\hline
\end{tabular}




\begin{tabular}{|l|l|l|l|} 
United Kingdom & 13 & 15 & 19 \\
\hline Austria & 15 & 23 & 11 \\
\hline Spain & 17 & 26 & 41 \\
\hline Italy & 19 & 27 & 35 \\
\hline
\end{tabular}

Source: Adaption from Bravo (2014), World Economic Forum (2015) and United Nations (2015)

To see if there is a relationship between the positions occupied by the ten countries from Table 3 in the three rankings, we have conducted another bivariate correlation analysis, based on Spearman coefficient. The results of this analysis can be seen in Table 4.

Table 4: Correlation between the positions of the ten countries from Table 3 in the HSDI, HDI and HCI rankings, in 2014

\begin{tabular}{|c|c|c|c|c|c|}
\hline & & & HSDI & HDI & HCI \\
\hline \multirow[t]{3}{*}{$\begin{array}{l}\text { Spearman's } \\
\text { rho }\end{array}$} & HSDI & $\begin{array}{l}\text { Correlation Coefficient } \\
\text { Sig. (2-tailed) } \\
\mathrm{N}\end{array}$ & $\begin{array}{l}1,000 \\
10\end{array}$ & $\begin{array}{l}, 766^{* *} \\
, 010\end{array}$ & $\begin{array}{l}, 600 \\
, 067 \\
10\end{array}$ \\
\hline & HDI & $\begin{array}{r}\text { Correlation Coefficient } \\
\text { Sig. (2-tailed) } \\
\mathrm{N}\end{array}$ & $\begin{array}{l}, 766^{* *} \\
, 010 \\
10 \\
\end{array}$ & 1,000 & $\begin{array}{l}, 632^{*} \\
, 050 \\
10 \\
\end{array}$ \\
\hline & HCI & $\begin{array}{r}\text { Correlation Coefficient } \\
\text { Sig. (2-tailed) } \\
\mathrm{N}\end{array}$ & $\begin{array}{l}, 600 \\
, 067 \\
10\end{array}$ & $\begin{array}{l}, 632^{*} \\
, 050\end{array}$ & $\begin{array}{l}1,000 \\
10\end{array}$ \\
\hline
\end{tabular}

Source: Own research

As we can see from Table 4, there is a quite strong positive correlation between the positions of the ten EU states in the HSDI, HDI and HCI rankings. However, compared to the results obtained for 2010, the correlations are weaker. Yet, the results presented in Table 4 allow us to assume that the highly developed EU states have high level of human capital and also pay attention to the environment.

\section{Conclusions}

This paper provides both theoretical and empirical evidences, on the EU states, to sustain the idea according to which the human capital is directly influencing the sustainable development. According to the literature, better educated and healthier people will have a higher level of productivity and creativity and, therefore, will have better employment opportunities and will earn higher incomes. Thus, it can be assumed that a country with a higher stock of human capital will experience higher growth rates.

The awareness regarding the environmental issues can be raised through education. In this context, several concepts have emerged: 'green skills', 'green graduates' and 'green innovations'. All these three, essential in the transition to a green economy, are related between them: the 'green skills' are developed through the educational system and will help the 'green graduates' to actively engage in protecting the environment. Moreover, these individuals will generate 'green innovations' that will use more sustainable the natural resources.

A higher level of education may be correlated not only to a friendly environment, but also to a better political and community implication, a higher social cohesion and to a 
lower criminality rate. The explanation for the close connection between the human capital and the social cohesion is simple: a higher level of education leads to higher revenues, so to higher individual satisfaction, which will allow people to better cooperate between them.

All these theoretical aspects have also been tested by us with the help of the statistical analysis. We have focused on the top ten countries with the highest levels of HSDI in European Union, in 2010 and 2014. The results showed that these states are also included by the United Nations' report in the group of countries with "very high human development", in the analysed period. Regarding the level of human capital, we can see that some of the countries from the top positions in the HSDI ranking have also high levels of HCI.

Conducting a bivariate correlation analysis, based on the Spearman coefficient, we noticed that there is a strong positive correlation between the positions of the ten EU states in the HSDI, HDI and HCI rankings, both in 2010 and in 2014. However, in 2014 the correlations are weaker. These results lead to the conclusion that the states with the highest level of development in EU have also taken into consideration the environmental issues, in order to ensure a sustainable development. Moreover, since the countries placed on the highest positions in the HSDI ranking are also among the states with the highest levels of HCI, we can say that, in the case of these states, the human capital is an important factor for obtaining a sustainable development.

\section{Acknowledgement}

This work was funded by "Alexandru Ioan Cuza" University of Iasi, through the project no. 20/03.12.2015, in the competition Grants for young researchers of UAIC.

\section{References}

Barro, R.J.(1996).Health and Economic Growth. World Health Organization.

Barro, R.J.\& Sala-i-Martin, X.(1995).Economic Growth. New York: McGraw Hill.

Baumol, W.J., Nelson, R.R. \& Wolf, E.N. (eds.)(1994).Convergence of Productivity: Cross-national studies and historical evidence. Oxford: Oxford University Press.

Bravo, G. (2014). The Human Sustainable Development Index: New calculations and a first critical analysis.Ecological Indicators, 37(A), 145-150, doi:10.1016/j.ecolind.2013.10.020.

Cedefop (2012).Green Skills and Environmental Awareness in Vocational Education andTraining. Luxembourg: European Commission.

Clemente, J., Marcuello, C., Montañes, A.\& Pueyo, F.(2004).On the international stability of health care expenditure functions: are government and private functions similar? Journal of Health Economics, 23 (3), 589-613.

Dwiningrum, S.I.A. (2013). Nation's Character Education Based on the Social Capital Theory.Asian Social Science, 9(12), 144-155.

European Commission.(2015).Employment, Human Capital and Social Cohesion. Retrieved fromhttp://ec.europa.eu/regional policy/ro/atlas/programmes/20142020/cyprus/2014cy05m9op001

Freeman, R.B. (2000). Does the booming economy help explain the drop in crime? In: U.S. Department of Justice, Perspectives on Crime and Justice: 1999-2000, Lectures Series.

Harmon, C., Oosterbeek, H. \& Walker, I.(2000).The Returns to Education. A review of Evidence, Issues and Deficiencies in the Literature.London: Center for the Economics of Education, London School of Economics and Political Science. 
ILO. (2013). Skills and Occupational Needs in Renewable Energy. Retrieved fromhttp://www.ilo.org/wcmsp5/groups/public/---ed emp/--ifp skills/documents/publication/wcms 168354.pdf

Kelly, M.(2000). Inequality and crime.Review of Economics and Statistics, 82(4), 530-539.

Lall, S.\& Kramer-Mbula, E. (2005).Is African industry competing?QEH Working Paper No. 122, University of Oxford.

Lange, F. \& Topel, R. (2006). The social value of education and human capital. In E. Hanushek, F. Welch (eds.), Handbook of the Economics of Education. Amsterdam: Elsevier.

Leigh, J. (1998). The social benefits of education: a review article.Economics of Education Review, 17(3), 363-368.

Lochner, L.(1999). Education, Work and Crime: Theory and Evidence.Working Paper no. 465, Rochester Center for Economic Research.

Marshall, A.(1890).Principles of Economics. London: Macmillan.

McMahon, W. (1999). Education and Development: Measuring the Social Benefits. New York: Oxford University Press.

Mora, J. G., Pavlakovich-Kochi, V.\& Marmalejo, F. (2006).Supporting the Contribution of Higher Education Institutions to Regional Development. Peer ReviewReport: Nuevo León, Mexico. Paris: OECD.

OECD. (2008). A profile of student performance in science.In:PISA 2006: ScienceCompetencies for Tomorrow's World, Volume 1: Analysis. OECD Publishing.

OECD. (2009). Green at Fifteen? How 15-year-olds perform in environmental science and geoscience in PISA.

Retrieved from http://www.oecd.org/edu/school/programmeforinternationalstudentassessmentpisa/greenatfifte enhow15-year-oldsperforminenvironmentalscienceandgeoscienceinpisa.htm

OECD. (2012a).OECD Employment Outlook 2012. OECD Publishing.Retrieved from http://dx.doi.org/10.1787/empl outlook-2012-en

OECD. (2012b).OECD Environmental Outlook to 2050. OECD Publishing.Retrieved fromhttp://dx.doi.org/10.1787/9789264122246-en

Olaniyan, D.A.\&Okemakinde, T. (2008). Human Capital Theory: Implications for Educational Development. European Journal of Scientific Research, 24(2), 157- 162.

Salazar-Xirinachs, J., Nübler, I. \& Kozul-Wright, R. (2014).Transforming Economies.Geneva:International Labour Organisation.

Schuller, T. (2001). The Complementary Roles of Human andSocial Capital.Canadian Journal of Policy Research, 2(1), 18-24.

Sianesi, B. \& Van Reenen, J.(2000).The returns to education: a review of macro-economic literature. London: Centre for the Economics and Education.

Slaus, I.\& Jacobs, G.(2011). Human Capital and Sustainability.Sustainability, 3, 97-154. doi:10.3390/su3010097.

Solow, R.M.(1956). A Contribution to the Theory of Economic Growth. Quarterly Journal of Economics, 70(1), 65-94.

Sturm, R. (1993). How do Education and Training Effect at Country's Economic Performance? A Literature Review. Santa Monica: RAND.

Swan, T. W.(1956). Economic Growth and Capital Accumulation.Economic Record, 32(63), 334-361.

Togtokh, C. (2011).Time to stop celebrating the polluters.Nature, 479(7373), 269. doi: 10.1038/479269a.

United Nations.(2015).Human Development Report. Retrieved from http://hdr.undp.org/sites/default/files/hdr_2015 statistical annex.pdf

Wilkinson, R. \& Marmot, M. (2003).Social determinants of health. The solid facts. $2^{\text {nd }}$ edition, World Health Organization.

World Economic Forum. (2013).The Human Capital Report. Retrieved from http://www3.weforum.org/docs/WEF HumanCapitalReport 2013.pdf

World Economic Forum. (2015).The Human Capital Report.Retrieved fromhttp://www3.weforum.org/docs/WEF Human Capital Report 2015.pdf 